\title{
Antioxidant, antibacterial properties and the light barrier assessment of raw and purified melanins isolated from Citrullus lanatus (watermelon) seeds
}

\author{
ŁUKASZ ŁOPUSIEWICZ
}

Center of Bioimmobilisation and Innovative Packaging Materials

Faculty of Food Sciences and Fisheries

West Pomeranian University of Technology in Szczecin

Janickiego 35

71-270 Szczecin, Poland

e-mail: lukasz.lopusiewicz@zut.edu.pl

\section{Summary}

Introduction: The nutritive value and terapeuthic activity of watermelon seeds is known, but up to day no studies on isolation and characterisation of their melanin were conducted.

Objective: The aim of the study was to evaluate the antioxidant, antibacterial and light barrier properties of raw and purified melanins isolated from watermelon seeds.

Methods: Native melanin was isolated from seeds by alkaline extraction. Obtained pigment was purified by acid hydrolysis. Chemical tests and FT-IR analysis were conducted to determine the melanin nature of the isolated pigments. UV-Vis, transmittance and colour properties were evaluated spectrophotometrically. Antioxidant activity was determined using ABTS and antibacterial activity through a well diffusion method.

Results: The results of the study demonstrated that melanins isolated from watermelon seeds had antioxidant, light barrier and antibacterial properties. A purified form of melanin had higher antioxidant activity and light barrier properties than the raw form. Both melanins inhibited the growth of Enterococcus faecalis and Pseudomonas aeruginosa.

Conclusions: Watermelon seeds may be considered as a promising source of natural melanin which possess remarkable therapeutic action that can support the traditional use of this plant in the ethnomedicine.

Key words: melanin, Citrullus lanatus, watermelon, antioxidants, antibacterials, light barrier 


\section{INTRODUCTION}

Cucurbitaceae is a large plant family consisting of 120 genera and approximately 825 species typically distributed in tropical countries, poorly represented in the temperate regions. The vegetable crops of family Cucurbitaceae are important in horticulture, mostly grown for their sweet and juicy fruit in warm climates all over the world. Cucurbitaceae are an important source of food, like: pumpkin (Cucurbita pepo), melon (Cucumis melo), cucumber ( $\mathrm{Cu}$ cumis sativa), watermelon (Citrullus lanatus), bottle gourd (Lagenaria siceraria) and sponge gourd (Luffa cylindrica) [1-4]. The Citrullus lanatus L. is one of the most popular species, with high water content, which can be as high as $92 \%$ of total weight, found in most parts of Africa, Asia, United States and Russia [5]. It is an important horticultural crop, mainly harvested for juice and juice concentrates, being an excellent source of vitamins, such as vitamin A and C $[2,5,6]$. Although seeds are not routinely eaten with pulp, constitute about 1 to $4 \%$ of total fruit weight. These seeds are discarded each year, either as cheap forage or simply thrown away [5]. Seeds are often disposed as waste since there are no current commercial utilisation purposes, but they are a promising source of useful compounds due to their possible nutritional properties $[5,7]$.

Watermelon seeds are known to be highly nutritional. They are rich source of proteins, vitamins B, minerals (such as magnesium, potassium, phosphorous, sodium, iron, zinc, manganese and copper) and fat as well as phytochemicals [1-3, 8]. Seeds contain polyunsaturated fatty acids such as omega-6 (linoleic acid), monounsaturated fatty acids, such as omega-9 (oleic acid). They also consist of saturated fatty acids, such as palmitic acid and stearic acid [2]. C. lanatus seeds were found to be rich in $\gamma$-sitosterol, $\beta$-sitosterol, vitamin $\mathrm{E}$ and lupeol. They also contain polyphenols, saponins, alkaloids and flavonoids $[2,9,10]$. The seeds are small, dark brown or light (depending on the variety), smooth, $0.4-1.1 \mathrm{~cm}$ long and $0.2-0.3 \mathrm{~cm}$ wide $[1,11,12]$. The seeds of watermelons are known to have economic benefits especially in countries where cultivation is increasing. The seeds can be used to prepare snacks, milled into flour and used for sauces [12]. Oil from seeds is used in cooking and incorporated in the cosmetic industry. In spite of various potential applications, watermelon seeds are often discarded, while the fruit is eaten. There is also limited literature on the effect of the variety of nutritional, phytochemical and antioxidant properties of watermelon seeds [3].
C. lanatus has been used for centuries in treatment of various ailments. It is an important medicinal plant in the Ayurveda and Indian traditional systems of medicine. The plant is rich in flavonoids, alkaloids, saponins, glycosides, tannins and phenols. Its nutritive values are also beneficial to human health. The plant has been extensively studied by various researchers for its pharmacological activities and therapeutic approaches such as antibacterial, antifungal, antimicrobial, antiulcer, antioxidant, antidiabetic, anti-inflammatory, gastroprotective and analgesic, laxative, antigiardial, hepatoprotective, against prosthetic hyperplasia and also atherosclerosis. The fruit is used in cooling, strengthening, as an aphrodisiac and astringent to the bowels, indigestible, expectorant, diuretic, and a stomachic as well as a blood purifier. It also allays thirst, cures biliousness, sore eyes, scabies and itches $[1,4,9,10,13]$.

Melanins have been isolated from a variety of phylogenic sources: animals [14], plants (including seeds) [15-21], bacteria [22, 23] and fungi [24, 25]. Melanins are commonly represented as black and brown pigments, the high molecular weight heterogenous polymers derived from the oxidation of monophenols and subsequent polymerization of intermediate o-diphenols and quinones [26]. Melanins are types of pigments, possessing broad biological activities including antioxidant, radioprotective, thermoregulative, chemoprotective, antitumor, antiviral, antimicrobial, immunostimulating and anti-inflammatory [14-26]. Based on these features, natural melanin has the potential to be of great value and application in the fields of pharmacology, cosmetics and functional foods [27]. However, wider knowledge on the pharmacological and biological activities of melanins from C. lanatus is very limited. In recent years there has been a revival of interest regarding the development of natural colorants for use as food additives, and in the cosmetic and pharmaceutical industries. This has been encouraged by strong consumer demand, as synthetic colorants are frequently perceived as undesirable or harmful [28]. Owing to the high toxicity of synthetic compounds, the search for new natural colorants with antiradical, light barrier and antimicrobial properties, still remains a challenge for modern science.

While a lot of information abounds in the properties and oil content of watermelon seeds, there is dearth of information on the phytochemicals and radical scavenging potential of melanin from these seeds. The aim of this study was to investigate the antioxidant, antimicrobial and light barrier properties of raw and purified melanins isolated form 
C. lanatus. This represents a first report on the isolation and biological activities of melanins from watermelon seeds.

\section{MATERIAL AND METHODS}

\section{Plant material}

Fresh fruits of watermelon Crimson Sweet (Citrullus lanatus) were purchased in local market in Szczecin (Poland). Seeds were removed from flesh manually and rinsed three times with distilled water then dried at room temperature.

\section{Chemicals}

$\mathrm{NaOH}, \mathrm{HCl}, \mathrm{FeCl}_{3}, \mathrm{AgNO}_{3}, \mathrm{H}_{2} \mathrm{O}_{2}$, acetone, ethanol, ethyl acetate, chloroform, DMSO and methanol (Chempur, Poland) were used to extract, purify and offer up a characterisation of the active substances from the C. lanatus seeds. ABTS and KBr (Sigma Aldrich) were also used in this study.

To verify the antimicrobial properties of any melanin, Mueller-Hinton broth and Mueller-Hinton agar media (Merck, Germany) were used. All media were prepared according to the Merck protocol.

\section{Extraction and purification}

The isolation and purification of melanin was performed as described by Łopusiewicz [24]. To summarise, $5 \mathrm{~g}$ of seeds were soaked by $50 \mathrm{ml}$ of $1 \mathrm{M}$ $\mathrm{NaOH}$, extracted in orbital shaker $\left(150 \mathrm{rpm}, 50^{\circ} \mathrm{C}\right.$, $24 \mathrm{~h}$ ) and centrifuged at $6000 \mathrm{rpm}$ for $10 \mathrm{~min}$ to remove plant tissue. Alkaline CL-RM (C. lanatus raw melanin) mixture was at first adjusted to $\mathrm{pH} 2.0$ with $1 \mathrm{M} \mathrm{HCl}$ to precipitate melanin, followed by centrifugation at $6000 \mathrm{rpm}$ for $10 \mathrm{~min}$ and a pellet was collected. Then, the pellet was hydrolyzed in $6 \mathrm{M}$ $\mathrm{HCl}\left(90^{\circ} \mathrm{C}, 2 \mathrm{~h}\right)$, centrifuged $(6000 \mathrm{rpm}, 10 \mathrm{~min})$ and washed by distilled water five times to remove acid. The pellet was washed with chloroform, ethyl acetate and ethanol three times to wash away lipids and other residues. Finally, the purified melanin (CL-PM - C. lanatus pure melanin) was dried, ground to a fine powder in a mortar and stored at $-20^{\circ} \mathrm{C}$ until testing.

\section{Chemical tests}

Different diagnostic tests, as described by Selvakumar et al. [29], were conducted on the CL-RM and CL-PM isolated melanins, in comparision with LDOPA melanin used as a melanin standard. The testing of organic solvents included ethanol, methanol, chloroform, ethyl acetate, acetone and DMSO.

\section{Ultraviolet-visible absorption and transmit- tance spectra}

Melanin solutions were prepared at concentration $0.1 \mathrm{mg} / \mathrm{ml}$ and UV-Vis absorption spectra were measured between 200 and $800 \mathrm{~nm}$. The absorbance ratio $\left(\mathrm{A}_{300} / \mathrm{A}_{600}\right)$ values and plots of optical densities against wavelenghts of melanins were also calculated $[18,24,29]$. Transmittance values were measured between 200 and $800 \mathrm{~nm}$ at $0.01 ; 0.05 ; 0.1 ; 0.5$ and $1 \mathrm{mg} / \mathrm{mL}$ for CL-RM and CL-PM; for L-DOPA melanin $0.01 ; 0.05 ; 0.1 ; 1 \mathrm{mg} / \mathrm{ml}$ concentrations were measured. All spectrophotometric assays were conducted in a Thermo Scientific Evolution 220 spectrophotometer.

\section{IR spectroscopy}

The IR spectra of melanins solid samples were obtained at a room temperature by attenuated total reflection with a Fourier transform infrared spectrometer (Perkin Elmer). The samples were evenly mixed with $400 \mathrm{mg} \mathrm{KBr}$, and pressed into tablets, then scanned at a range from $650 \mathrm{~cm}^{-1}$ to $4000 \mathrm{~cm}^{-1}$ (64 scans and $1 \mathrm{~cm}^{-1}$ resolution) $[18,28]$. The spectra were normalized, baseline corrected and analyzed using SPECTRUM software.

\section{The antioxidant activity (ABTS assay)}

The ABTS assay was performed according to Łopusiewicz [24]. Radical 2,2'-azino-bis(3ethylbenzothiazoline)-6-sulphonic acid (ABTS-+) was produced by mixing $7 \mathrm{mM}$ ABTS with $2.45 \mathrm{mM}$ potassium persulfate $(5 \mathrm{ml}$ of ABTS $+5 \mathrm{ml}$ of potassium persulphate $4.9 \mathrm{mM}$ ). The mixture was incubated in darkness at a room temperature for $16 \mathrm{~h}$, diluted with $7 \mathrm{mM}$ phosphate buffer ( $\mathrm{pH}$ 7.4) to reach an absorbance of between 1.0 and 1.2 at $734 \mathrm{~nm}$. For the ABTS assay, $50 \mu \mathrm{l}$ of melanin (CLRM, CL-PM, L-DOPA melanin; 0.0625; 0.125; 0.25, 
$0.5 ; 1 \mathrm{mg} / \mathrm{ml}$ ), or dissolvent as a control, were mixed with $1.95 \mathrm{ml}$ of ABTS + + solution, incubated in darkness for $10 \mathrm{~min}$ at $37^{\circ} \mathrm{C}$, and then the absorbance was measured at $734 \mathrm{~nm}$ and antioxidant activity (\%AA) was calculated as $\% A A=\left[\left(\mathrm{A}_{\mathrm{c}}-\mathrm{A}_{\mathrm{m}}\right) / \mathrm{A}_{\mathrm{c}}\right] \times 100$; where $A_{c}$ and $A_{m}$ are absorbances for control and melanin sample, respectively.

\section{The visual colour of melanins}

The visual colour of melanin solutions $(0.1 \mathrm{mg} / \mathrm{ml})$ values were measured by a Konica Minolta CR-5 colorimeter with the Hunter LAB colour system. The colour values were expressed as $L^{*}$ (brightness/darkness), $\mathrm{a}^{*}$ (redness/greenness) and $\mathrm{b}^{\star}$ (yellowness/blueness) as an averages of five measurements with standard deviations.

\section{The antibacterial activity of isolated melanins}

Test microorganisms, including Bacillus cereus ATCC14579, Enterococcus faecalis ATCC29212, Escherichia coli DSMZ1576, Pseudomonas aeru- poured on $90 \mathrm{~mm}$ Petri dishes. Wells were cut out by sterile tips ( $9 \mathrm{~mm}$ diameter) in triplicate on each plate, and $100 \mu \mathrm{l}$ of melanin solutions at $0.1 \mathrm{mg} / \mathrm{ml}$ in DMSO were placed in the wells. DMSO served as a control. Plates were incubated at $37^{\circ} \mathrm{C}$ for $24 \mathrm{~h}$. The inhibition zones were measured after incubation. The results were presented as an average of three samples with standard deviation.

Ethical approval: The conducted research is not related to either human or animal use.

\section{RESULTS}

The results of the study demonstrated that raw and purified black pigments from $C$. lanatus had antioxidant, antibacterial and light barrier properties. The CL-RM and CL-PM pigments presented all of the physical and chemical properties common to natural melanins, and the experimental data within this work were found to be comparable to those reported in literature. The results are summarized in Table 1 , which also shows the properties of the L-DOPA melanin sample used as a melanin standard.

Table 1.

Diagnostic tests for melanins

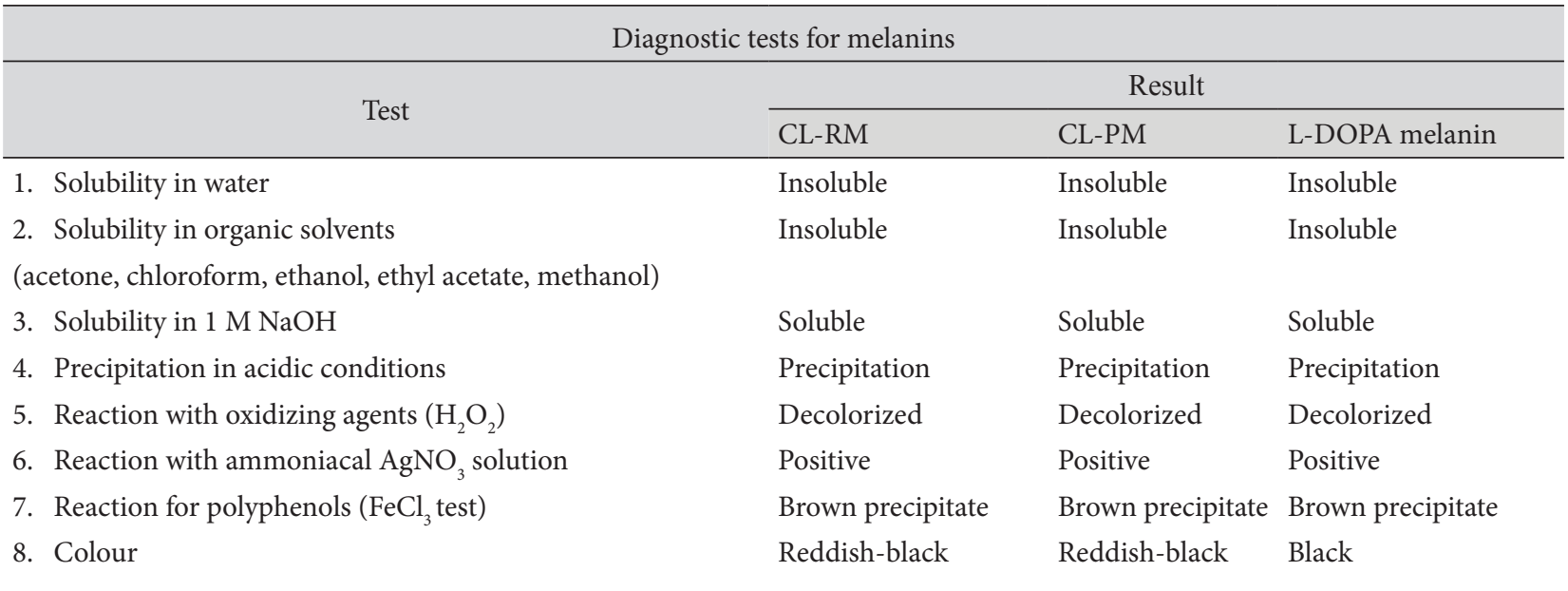

Positive - gray-coloured silver precipitate on tube side

ginosa ATCC27853 and Staphylococcus aureus DSMZ346 were separately cultivated in MuellerHinton broth. The antibacterial activity was tested through a well diffusion method. $50 \mathrm{ml}$ of MuellerHinton broth was inoculated by a single bacterial strain and incubated at $37^{\circ} \mathrm{C}$ for $24 \mathrm{~h}$. Mueller-Hinton agar was autoclaved and on reaching approx. $45^{\circ} \mathrm{C}, 200 \mu \mathrm{l}$ of bacterial suspension was added to $20 \mathrm{ml}$ of the medium, vigorously vortexed and
Figure 1 shows CL-RM and CL-PM have maximum absorption peaks at $221 \mathrm{~nm}$ and $223 \mathrm{~nm}$, respectively, and exhibited an exponential decrease in the visible region. This CL-RM and CL-PM behaviour was similar to the melanin synthetized from LDOPA, which is used as a melanin standard. Figure 2 shows that the log of optical density of melanin solutions when plotted against wavelength produces straight lines with negative slopes ranging from 

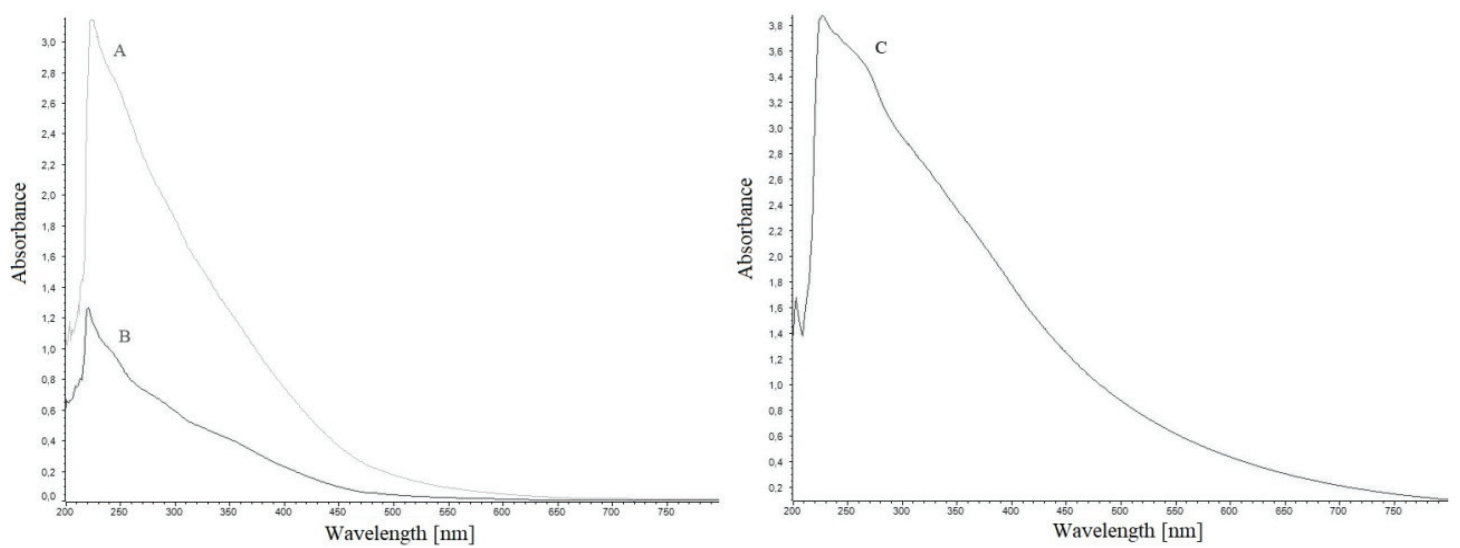

Figure 1.

The absorbance of CL-PM (A), CL-RM (B) and L-DOPA melanin (C)

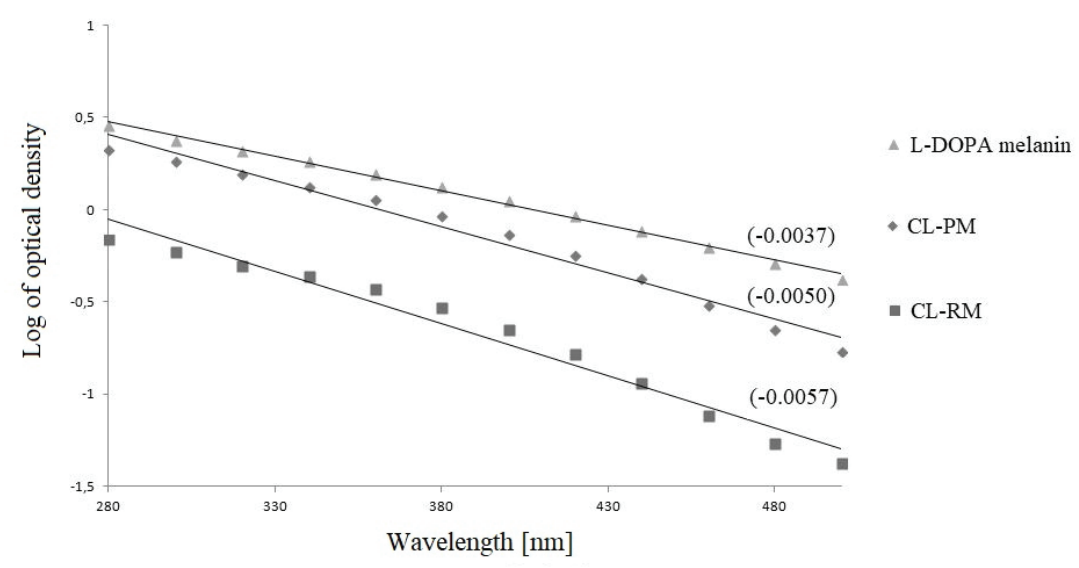

Figure 2.

Plot of log of optical density against wavelenght for L-DOPA melanin, CL-PM and CL-RM

-0.0037 and -0.0050 to -0.0057 , for L-DOPA melanin, CL-PM and CL-RM, respectively.

The light barrier properties of CL-RM, CL-PM and L-DOPA melanin are shown in figure 3. It was noted that in all analysed concentrations, the CLRM transmittance values were higher than those of corresponding CL-PM, which suggests that in purified form, melanin had better light barrier properties, even when the transmittance values of CL-PM were smaller than the synthetic melanin.

Table 2.

The visual colour values of CL-RM, CL -PM and L-DOPA melanin (mean \pm SD, $n=5$ )

\begin{tabular}{lccc}
\hline & \multicolumn{1}{c}{$\mathrm{L}^{*}$} & $\mathrm{a}^{*}$ & $\mathrm{~b}^{*}$ \\
\hline CL-RM & $97.87 \pm 0.00$ & $-1.71 \pm 0.01$ & $10.42 \pm 0.03$ \\
CL-PM & $91.85 \pm 0.04$ & $-0.84 \pm 0.00$ & $32.85 \pm 0.05$ \\
L-DOPA melanin & $74.87 \pm 0.02$ & $10.56 \pm 0.01$ & $47.74 \pm 0.01$ \\
\hline
\end{tabular}

$\mathrm{L}^{*}$ - brightness/darkness

$\mathrm{a}^{*}$ - redness/greeness

$\mathrm{b}^{*}$ - yellowness/blueness
The colour values of CL-RM, CL-PM and synthetic melanin are shown in table 2. Results from the colorimeter indicated that CL-PM presented lower $L^{*}$ value, and higher $\mathrm{a}^{*}$ and $\mathrm{b}^{*}$ values than CL-RM in Hunter Lab colour system.

In general, the \%AA values of CL-PM were higher than those of CL-RM, and the \%AA of both melanins were lower than the corresponding concentrations of L-DOPA melanin, as shown in table 3.

Figure 4 shows the IR-spectra of CL-RM, CL-PM and L-DOPA melanin. Extra display broad absorption bands at $3600-3000 \mathrm{~cm}^{-1}$ were noted, attributed to stretching vibrations of $\mathrm{C}-\mathrm{H}, \mathrm{N}-\mathrm{H}$ and/or $\mathrm{O}-\mathrm{H}$ groups. The $\mathrm{C}-\mathrm{H}$ could be due to the presence of aromatic rings, with strong bands at $1627 \mathrm{~cm}^{-1}$ and $1625 \mathrm{~cm}^{-1}$, for CL-RM and CL-PM, respectively, which corresponds to the vibration of aromatic $\mathrm{C}=\mathrm{C}$, and more intense in CL-PM. Two peaks at $2919 \mathrm{~cm}^{-1}$ to $2863 \mathrm{~cm}^{-1}$ in both melanins may result from the oscillation of aliphatic $\mathrm{CH}_{2}$ and $\mathrm{CH}_{3}$ groups. The 

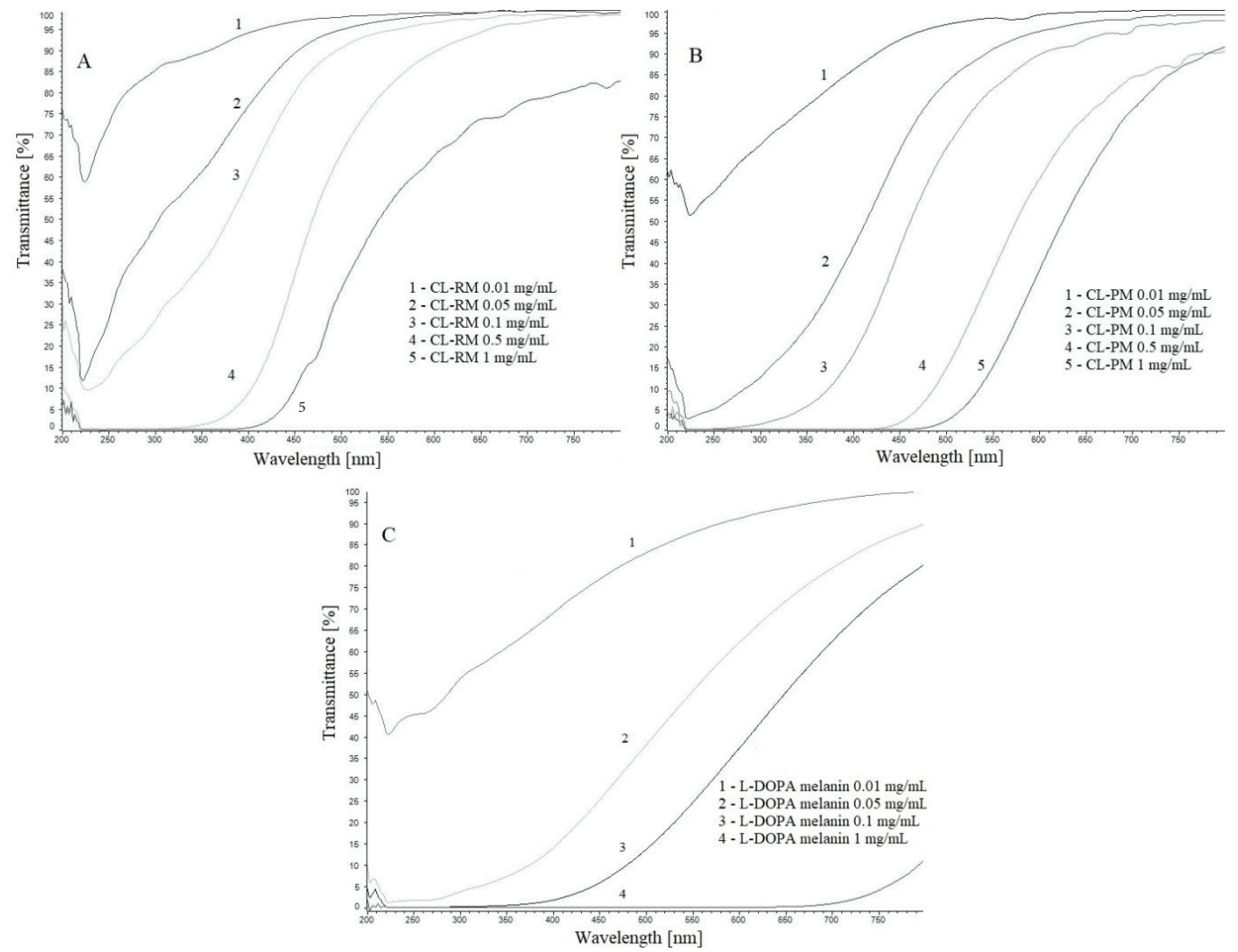

Figure 3.

Transmittance values [\%] of CL-RM (A), CL-PM (B) and L-DOPA melanin (C)

Table 3.

The antioxidant activity (\%AA values, [\%]) of CL-RM, CL-PM and L-DOPA melanin at various concentrations $[\mathrm{mg} / \mathrm{ml}]($ mean $\pm \mathrm{SD}, n=3)$

\begin{tabular}{llllll}
\hline CL-RM $[\mathrm{mg} / \mathrm{ml}]$ & \%AA [\%] & CL-PM [mg/ml] & \%AA [\%] & $\begin{array}{l}\text { L-DOPA } \\
\text { melanin }[\mathrm{mg} / \mathrm{ml}]\end{array}$ & \%AA [\%] \\
\hline 0.0625 & $11.1 \pm 0.32$ & 0.0625 & $13.57 \pm 1.12$ & 0.0625 & $20.31 \pm 0.26$ \\
0.125 & $24.50 \pm 0.05$ & 0.125 & $16.59 \pm 0.32$ & 0.125 & $31.51 \pm 1.04$ \\
0.25 & $35.85 \pm 0.12$ & 0.25 & $26.82 \pm 0.11$ & 0.25 & $50.75 \pm 0.18$ \\
0.5 & $44.13 \pm 0.21$ & 0.5 & $49.06 \pm 0.28$ & 0.5 & $95.91 \pm 0.33$ \\
1 & $79.18 \pm 0.09$ & 1 & $92.48 \pm 0.17$ & 1 & $97.16 \pm 0.05$ \\
\hline
\end{tabular}

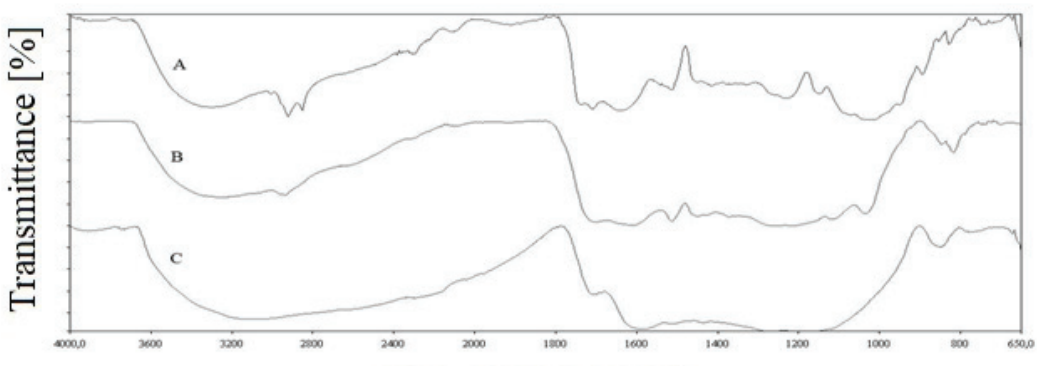

\section{A - CL-RM \\ B - CL-PM \\ C - L-DOPA melanin}

Wavenumber $\left[\mathrm{cm}^{-1}\right]$

Figure 4.

Infrared spectra of CL-RM, CL-PM and L-DOPA melanin 
bands at $1224 \mathrm{~cm}-1$ and $1221 \mathrm{~cm}-1$ due to $\mathrm{C}-\mathrm{N}$ and $\mathrm{C}-\mathrm{O}$, would support the presence of phenols and aromatic amines. It is difficult to state whether there is an amide group, as the $\mathrm{C}=\mathrm{O}$ group that it complements might be joined in the band corresponding to the aromatic $\mathrm{C}=\mathrm{C}$. There are differences between the CL-RM and CL-PM spectra which may be a result of the purification process.

The results of an antibacterial activity assessment of CL-RM and CL-PM are demonstrated in table 4. The zones of growth inhibition of E. faecalis and P. aeruginosa were $11.3 \pm 0.3 \mathrm{~mm}$ and $13.9 \pm 0.2 \mathrm{~mm}$ for CL-RM, respectively, while CL$\mathrm{PM}$, were $11.2 \pm 0.2 \mathrm{~mm}$ and $12.4 \pm 0.4 \mathrm{~mm}$. No inhibition on B. cereus, E. coli and S. aureus was observed. been obtained for some fungi $[24,25,29]$. CL-RM and CL-PM had straight lines with negative slopes of -0.0057 and -0.0050 , respectively, indicating that black pigments are melanins.

Infrared spectroscopy has been used in the chemical structure study of many melanins. It has been suggested that identical melanin structures do not exist in nature and their chemical characterization is a complicated task. Their composition depends not only on their different monomeric units, but also on environmental conditions during polymerization. Infrared spectrometric techniques offer information on the main functional groups in the melanin structure $[18,24,27,28]$. A detailed comparative analysis of the infrared spectra of the melanins studied may supply valuable information on the effect of each

Table 4.

The antibacterial activity of CL-RM, CL-PM and L-DOPA melanin (zones of growth inhibition, mm), (mean \pm SD, $n=3$ )

\begin{tabular}{lccccc}
\hline CL-RM $[\mathrm{mg} / \mathrm{ml}]$ & BC & EC & EF & PA & SA \\
\hline CL-RM & - & - & $11.3 \pm 0.3$ & $13.90 \pm 0.2$ & - \\
CL-PM & - & - & $11.2 \pm 0.2$ & $12.4 \pm 0.4$ & - \\
L-DOPA melanin & - & - & $11.4 \pm 0.2$ & $13.1 \pm 0.1$ & - \\
\hline
\end{tabular}

- - no inhibition zone, BC - B. cereus ATCC14579, EC - E. coli DSMZ1576, EF - E. faecalis ATCC29212, PA - P. aeruginosa ATCC27853, SA - S. aureus DSMZ346

\section{DISCUSSION}

Through the work on this study, it becomes clear that melanins isolated from C. lanatus possess promising antioxidant, light barrier and antibacterial properties.

Chemical tests and FT-IR conducted on isolated pigments that were compared to the synthetic LDOPA melanin clearly demonstrated that they are melanins. Purified melanin (CL-PM) was obtained by acid hydrolysis, repeated precipitation and purification through the use of organic solvents. The structure of melanin polymers is little understood and an accurate definition of melanin is still required. However, the following criteria indicate melanin to be black/brown in colour, insoluble in water and most other organic solvents, resistant to degradation by hot or cold acids, bleached by oxidizing agents and solubilised by alkali solutions [30].

A decrease in absorption with increasing wavelength is almost linear in melanins. Hence, the slopes of linear plots are often used to identify melanin. The $\log$ of optical density of melanin solutions when plotted against wavelength produces straight lines with negative slopes. Such characteristic lines have treatment step used to purify the melanin and the distinct functional groups prevailing in the various samples.

There was no absorption peak between 260$280 \mathrm{~nm}$ in the UV spectra, indicating, that melanins do not contain proteins and nucleic acids [31]. The UV-Vis absorption spectra of the impure (RM) and purified (PM) melanins were similar to those reported in other literature.

In general, melanins are dark because they do not re-radiate the absorbed visible or invisible light, but transform the energy into rotational and vibrational activity within the molecule and then dissipate it as heat. This phenomenon protects melanised tissues against light-induced damage $[18,26]$. It was reported that the seed coat affected various factors, such as its water uptake, seed dormancy, seed quality due to colour pigments in seed coat and germination $[32,33]$. It is known that differences in the amount of some colour pigments result in colour differences of the seed coats. For example, it was found that in rapeseed, water uptake and tolerance to excessive water was significantly correlated with seed coat colour and melanin pigment amount. Seeds having red and black coat were found to have higher melanin 
pigment. In addition, coloured types had a slow water uptake, low electrical conductivity and high tolerance to slow water uptake. In yellow-coloured seeds, lower melanin content and faster water uptake were observed [34]. Nerson [32] found that immature seeds of watermelon cv. Sugar Baby take more water than mature seeds, however the study presented no data on seed coat colour [32, 33].

The high antioxidant activity of melanins was expected because the protection against UV-radiation and free radical scavenging are their main functions $[18,26]$. The effects of free radicals on human beings are closely related to toxicity, disease and aging [5]. Most living species have an efficient defence system to protect themselves against the oxidative stress induced by Reactive Oxygen Species (ROS). The antioxidants can interfere with the oxidation process by reacting with free radicals, chelating free catalytic metals and also by acting as oxygen scavengers [10]. The ability of melanin to scavenge ROS, such as singlet oxygen, hydroxyl radical and superoxide anion, has been firmly established in model systems, suggesting that melanin could protect pigment cells against oxidative stress that may accompany the formation of ROS in cells [5]. Even though critical damage to oxidatively stressed cells may result from the reaction of crucial cellular constituents with ROS, an efficient antioxidant may protect the cells by scavenging other oxidizing radicals such as the peroxyl radical, and by interacting with molecular oxygen [35]. There are reports about the antioxidant activity of C. lanatus seeds extracts, and the potency of antioxidant power depends on the type of extract [1$4,10]$. According to Rahman et al. n-hexane extract from $C$. lanatus seeds exhibit the highest antioxidant activity [10]. It is widely accepted that antioxidant phytochemicals in foods have many health benefits including the prevention of various diseases associated with oxidative stress such as cancer, cardiovascular disease, neuro-degeneration and diabetes [5]. Melanins may be extracted only in alkaline conditions, thus in previous works conducted by other authors, using organic solvents and water were possibly not considered as a constituent of total antioxidants of $C$. lanatus seeds. The high antioxidant activity of melanins isolated from various sources have been reported by the other authors [14-29].

The $\mathrm{A}_{300} / \mathrm{A}_{600}$ ratios offer information about the oxidation state and the range size of melanin molecules [18]. Melanin oxidation induces lower absorbance values at $600 \mathrm{~nm}\left(\mathrm{~A}_{600}\right)$, and the $\mathrm{A}_{300} / \mathrm{A}_{600} \mathrm{ab}$ sorbance ratio was proposed as a measure of the oxidation extent, high values corresponded to greater oxidized melanin molecules. It has also been argued that during melanin oxidation, phenolics are converted to semiquinones or quinones, which produce more oxidized (higher $\mathrm{A}_{300} / \mathrm{A}_{600}$ absorbance ratios) and smaller melanin molecules (molecular weight $<$ $1000 \mathrm{Da}$ ) [28]. CL-RM showed higher value (39.73) than its corresponding pure CL-PM (38.38) and LDOPA melanin (16.00). These data support the fact than CL-RM are a more complex mixture of melanin molecules that those of CL-PM, with a variability in size and degree of oxidation. These data are consistent with results of Cuevaz-Juárez et al. [18], Łopusiewicz [24, 25] and also with observations made by Hung et al. [36] who noted that oxidized and reduced melanins obtained from fruits, fungi and black tea have differences in their absorption spectra. Reduced forms of melanin have phenolic form prevalence, which when oxidized, show a preponderance for quinone forms.

Antimicrobial assessment results are partially consistent with results found by other authors. Both melanins showed antibacterial activity against P. aeruginosa and $E$. faecalis. No antibacterial activity towards B. cereus, E. coli and S. aureus was observed. In previous works, crude extracts of watermelon seeds using hot and cold water, methanol and ethanol showed the antimicrobial activity using the standard disc diffusion assay method against pathogenic microorganisms including B. cereus, E. coli, Klebsiella pneumoniae, $P$. aeruginosa and $S$. aureus $[1,13,37]$. In another study, crude extracts of C. lanatus, C. colocynthis and C. vulgaris were very effective against bacteria and some fungal strains. An ethanolic extract was found to be more effective than respective aqueous and chloroform extracts [1]. The zone of inhibition was found to be at a maximum in E. coli and minimum in S. aureus. The fungal zone of inhibition was found more in Candida albicans and less in Trichosporon begelii $[1,38,39]$. The results of the study are supported by results of Łopusiewicz $[24,25]$, who noted antimicrobial activity of melanins from Exidia nigricans and Scleroderma citrinum against E. faecalis and P. aeruginosa. Helan Soundra Rani et al. [40] observed the antimicrobial activity of melanin isolated from halophilic black yeast Hortaea werneckii. Laxmi et al. [23] observed that the growth of $P$. aeruginosa was inhibited in the presence of melanin obtained from Providencia rettgeri, but in their study some Bacillus species were sensitive to melanin. $\mathrm{Xu}$ et al. [41] analysed the antimicrobial activity of melanin from Lachnum YM30 and noted that it was active against a wide spectrum of bacteria including $S$. aureus. The authors suggest 
that melanin antibacterial activity might result from damage of the cell membrane and affect the bacteria membrane function. A discrepancy in melanin antimicrobial activity may result from differences within the molecule structure and composition [42]. The antimicrobial effects of melanin from $C$. lanatus seeds against the studied bacteria suggest that, it possess remarkable therapeutic action that can support the traditional use of this plant in the treatment of bacterial diseases such as diarrhoea, gastrointestinal infection, as well as respiratory and skin diseases [1].

Conflict of interest: Author declares no conflict of interest.

\section{REFERENCES}

1. Deshmukh CD, Jain A, Tambe MS. Phytochemical and pharmacological profile of Citrullus lanatus (Thunb). Biolife 2015; 3(2):483-488. doi: http://dx.doi.org/10.17812/blj2015.32.18

2. Mehra M, Pasricha V, Gupta R. Estimation of nutritional, phytochemical and antioxidant activity of seeds of musk melon (Cucumis melo) and water melon (Citrullus lanatus) and nutritional analysis of their respective oils. J Pharmacogn Phytochem 2015; 3(6):98-102.

3. Tabiri B, Agbenorhevi JK, Wireko-Manu FD, Ompouma EI. Watermelon seeds as food: nutrient composition, phytochemicals and antioxidant activity. IJNFS 2016; 5(2):139-144. doi: http:// dx.doi.org/ 10.11648/j.ijnfs.20160502.18

4. Adetutu A, Olorunnisola OS, Owoade OA. Nutritive values and antioxidant activity of Citrullus lanatus fruit extract. Food Nutr Sci 2015; 6:1056-1064. doi: http://dx.doi.org/10.4236/ fns.2015.611109

5. Seidu KT, Otutu OL. Phytochemical composition and radical scavenging activities of watermelon (Citrullus lanatus) seeds constituents. Croat J Food Sci Technol 2016; 8(2):83-89. doi: http:// dx.doi.org/10.17508/CJFST.2016.8.2.07

6. Edwards AJ, Vinyard BT, Wiley ER, Brown ED, Collins JK, Perkins-Veazie P et al. Consumption of watermelon juice increase plasma concentrations of lycopene and $\beta$-carotene in humans. J Nutr 2003; 133:1043-1050.
7. Scheiber A, Stintzing FC, Carle R. By-products of plant food processing as a source of functional compounds - recent developments. Trends Food Sci Technol 2001; 12(11):401-413. doi: http:// dx.doi.org/10.1016/S0924-2244(02)00012-2

8. Wani AA, Sogi DS, Singh P, Wani IA, Shivhare US. Characterisation and functional properties of watermelon (Citrullus lanatus) seeds proteins. J Sci Food Agric 2011; 91:113-121. doi: http:// dx.doi.org/10.1002/jsfa.4160

9. Sani UM. Phytochemical screening and antidiabetic effect of extracts of the seeds of Citrullus lanatus in alloxan-induced diabetic albino mice. J Appl Pharm Sci 2015; 5(3):51-54. doi: http:// dx.doi.org/10.7324/JAPS.2015.50309

10. Rahman H, Manjula K, Anoosha T, Nagaveni K, Chinna Eswaraiah M, Bardalai D. In-vitro and antioxidant activity of Citrullus lanatus seeds extracts. Asian J Pharm Clin Res 2013; 6(3):152157.

11. Oyeleke GO, Olagunju EO, Ojo A. Functional and physiochemical properties of watermelon (Citrullus lanatus) seeds and seed-oil. IOSR-JAC 2012; 2(2):29-31. doi: http://dx.doi.org/10.9790/57360222931

12. Koocheki A, Razavi SMA, Milani E, Moghadam TM, Abedini M, Alamatiyan S et al. Physical properties of watermelon seed as a function of moisture content and variety. Int Agrophysics 2007; 21:349-359.

13. Erhirhie EO, Ekene NE. Medicinal values of Citrullus lanatus (Watermelon): Pharmacological review. IJRPBS 2013; 4(4):1305-1312.

14. Mbonyiryivuze A, Nuru ZY, Ngom BD, Mwakikunga B, Dhlamini SM, Park E et al. Morphological and chemical composition characterization of commercial sepia melanin. AJN 2015; 3(1):22-27. doi: http://dx.doi.org/10.12691/ajn-3$1-3$

15. Li H, Li J, Zhao Z. Characterisation of melanin isolated from apricot (Armeniaca sibirica) and its effect on hydrazine-induced rat hepatic injury. Sci Asia 2016; 42:382-391. doi: http://dx.doi. org/10.2306/scienceasia1513-1874.2016.42.382

16. Wang H, Pan Y, Tang X, Huang Z. Isolation and 
characterization of melanin from Osmanthus fragrans' seeds. LWT - Food Sci Technol 2006; 39(5):496-502. doi: http://dx.doi.org/10.1016/j. lwt.2005.04.001

17. Kannan P, Ganjewala D. 2009. Preliminary characterization of melanin isolated form frutis and seeds of Nyctanthes arbor-tristis. J Sci Res 1(3):655-661. doi: http://dx.doi.org/10.3329/jsr. v1i3.2005

18. Cuevas-Juárez E, Yuriar-Arredondo KY, PíoLeón JF, Montes-Avila J, López-Angulo G, DíazCamacho SP et al. Antioxidant and $\alpha$-glucosidase inhibitory properties of soluble melanins from the fruits of Vitex mollis Kunth, Randia echinocarpa Sessé et Mociño and Crescentia alata Kunth. J Funct Foods 2014; 9:78-88. doi: http://dx.doi. org/10.1016/j.jff.2014.04.016

19. Al-Tayib OA, El Tahir KE, Idriss MH, Eram KE, Hassib AM. Nigella sativa L. seeds melanin: A new hypoglycemic agent. Comparison with insulin in alloxan-diabetic rats. SAJP 2014; 3:332-335.

20. Chitturi S, Gopichand V, Vuppu S. Studies on protein content, protease activity, antioxidants potential, melanin composition, glucosinolate and pectin constitution with brief statistical analysis in some medicinally significant fruit peels. Der Pharmacia Lettre 2013; 5(1):13-23.

21. Sava V, Galkin B, Hung MY, Yang PC, Huang GS. A novel melanin-like pigment derived from black tea leaves with immuno-stimulating activity. Food Res Int 2001; 34:337-343. doi: http://dx.doi. org/10.1016/S0963-9969(00)00173-3

22. Kurian NK, Nair HP, Bhat SG. Melanin producing Pseudomonas stutzeri BTCZ10 from marine sediment at $96 \mathrm{~m}$ depth (Sagar Sampada cruise \#305). Int J Curr Biotechnol 2014; 2(5):6-11.

23. Laxmi M, Kurian NK, Smitha S, Bhat SG. Melanin and bacteriocin from marine bacteria inhibit biofilms of foodborne pathogens. Indian J Biotechnol 2016; 15(3):392-399.

24. Łopusiewicz Ł. Isolation, characterisation and biological activity of melanin from Exidia nigricans. WSN 2018; 91:111-129.

25. Łopusiewicz Ł. Scleroderma citrinum melanin: isolation, purification, spectroscopic studies with characterization of antioxidant, antibacterial and light barrier properties. WSN 2018; 94:114-129.

26. Solano F. Melanins: skin pigments and much more - types, structural models, biological functions, and formation routes. New J Sci 2014. doi: http://dx.doi.org/10.1155/2014/498276

27. Zhang M, Xiao G, Thring RW, Chen W, Zhou H, Yang H. Production and characterization of melanin by submerged culture of culinary and medicinal fungi Auricularia auricula. Appl Biochem Biotechnol 2015; 176:253-266. doi: http://dx.doi. org/10.1007/s12010-015-1571-9

28. Yao Z, Qi J, Wang L. Isolation, fractionation and characterization of melanin-like pigments from chestnut (Castanea mollissima) shells. J Food Sci 2012; 77(6):671-676. doi: http://dx.doi. org/10.1111/j.1750-3841.2012.02714.x

29. Selvakumar P, Rajasekar S, Periasamy K, Raaman N. Isolation and characterization of melanin pigment from Pleurotus cystidiosus (telomorph of Antromycopsis macrocarpa). World J Microbiol Biotechnol 2008; 24:2125-2131. doi: http:// dx.doi.org/10.1007/s11274-008-9718-2

30. Zhan F, He Y, Zu Y, Li T, Zhao Z. Characterisation of melanin isolated form a dark septate endophyte (DSE), Exophiala pisciphila. World J Microbiol Biotechnol 2011; 27:2483-2489. doi: http://dx.doi.org/10.1007/s11274-011-0712-8

31. Ye M, Wang Y, Qian M, Chen X, Hu X. Preparation and properties of the melanin from Lachnum singerianum. IJBAS-IJENS 2011; 11(3):51-58.

32. Nerson H. Effects of seed maturity, extraction practices and storage duration on germinability in watermelon. Sci Hort 2002; 93:245-256. doi: http://dx.doi.org/10.1016/S0304-4238(01)003326

33. Mavi K. The relationship between seed coat color and seed quality in watermelon Crimson sweet. Hort Sci (Prague) 2010; 37(2):62-69.

34. Zhang XK, Yang GT, Chen L, Yin JM, Tang ZL, Li JN. Physiological differences between yellowseeded and black-seeded rapeseed (Brassica napus L.) with different testa characteristics during artificial ageing. Seed Sci Technol 2006; 34:373-381. doi: http://dx.doi.org/10.15258/sst.2006.34.2.13 
35. Różanowska M, Sarna T, Land EJ, Truscott TG. Free radical scavenging properties of melanin: interaction of eu- and pheo-melanin models with reducing and oxidizing radicals. Free Radic Biol Med 1999; 26:518-525. doi: http://dx.doi. org/10.1016/S0891-5849(98)00234-2

36. Hung Y-Ch, Sava V, Makan S, Chen Tz-HJ, Hong M-Y, Huang GS. Antioxidant activity of melanins derived from tea: comparision beteen different oxidative states. Food Chem 2002; 78:233240. doi: http://dx.doi.org/10.1016/S03088146(01)00403-4

37. Adunola AT, Chidimma AL, Olatunde DS, Peter OA. Antibacterial activity of watermelon (Citrullus lanatus) seed against selected microorganisms. Afr J Biotechnol 2015; 14(14):1224-1229. doi: http://dx.doi.org/ 10.5897/AJB2014.14101

38. Thirunavukkarasu P, Ramanathan T. Screening of antimicrobial effects of watermelon. J Biol Sci 2010; 10:682-685. doi: http://dx.doi.org/10.3923/ jbs.2010.682.685
39. Sathya J, Shoba FG. Assessment of antimicrobial efficacy of Citrullus lanatus methanolic seed extract. J Chem Pharm Res 2014; 6(12):640-643.

40. Helan Soundra Rani M, Ramesh T, Subramanian J, Kalaiselvam M. Production and characterization of melanin pigment from halophilic black yeast Horatea werneckii. IJPRR 2013; 2(8):9-17.

41. Xu C, Li J, Yang L, Shi F, Yang L, Ye M. Antibacterial activity and a membrane damage mechanism of Lachnum YM30 melanin against Vibrio parahaemolyticus and Staphylococcus aureus. Food Control 2017; 73:1445-1451. doi: http://dx.doi. org/10.1016/j.foodcont.2016.10.048

42. Correa N, Covarrubias C, Rodas PI, Hermosilla G, Olate VR, Valdés C et al. Differential antifungal activity of human and cryptococcal melanins with structural discrepancies. Front Microbiol 2017; 8:1-13. doi: http://dx.doi.org/10.3389/ fmicb.2017.01292

\title{
Właściwości antyoksydacyjne, antybakteryjne i barierowe względem światła natywnych i oczyszczonych melanin wyizolowanych $\mathrm{z}$ nasion arbuza (Citrullus lanatus)
}

\author{
ŁUKASZ ŁOPUSIEWICZ
}

\author{
Centrum Bioimmobilizacji i Innowacyjnych Materiałów Opakowaniowych \\ Wydział Nauk o Żywności i Rybactwa \\ Zachodniopomorski Uniwersytet Technologiczny w Szczecinie \\ ul. Janickiego 35 \\ 71-270 Szczecin
}

e-mail: lukasz.lopusiewicz@zut.edu.pl 


\section{Streszczenie}

Wstęp: Wartość odżywcza i terapeutyczna nasion arbuza jest znana, ale dotychczas brak jest badań na temat izolacji i charakterystyki ich melanin.

Cel: Celem pracy było określenie właściwości antyoksydacyjnych, antybakteryjnych i barierowych względem światła natywnych i oczyszczonych melanin z nasion arbuza.

Metody: Natywna melanina została wyizolowana z nasion w środowisku zasadowym. Otrzymany pigment został oczyszczony w wyniku hydrolizy kwasowej. Przeprowadzono testy chemiczne oraz analizę FT-IR aby określić charakter otrzymanych barwników. Widma UV-Vis, transmitancję oraz kolor oznaczono spektrofotometrycznie. Właściwości antyoksydacyjne określono za pomocą ABTS a właściwości przeciwbakteryjne metodą dyfuzyjną-studzienkową.

Wyniki: Wyniki niniejszej pracy wskazują na to, że melaniny pozyskane z nasion arbuza charakteryzują się właściwościami antyoksydacyjnymi, barierowymi względem światła i przeciwbakteryjnymi. Oczyszczona melanina miała wyższe niż forma natywna właściwości przeciwutleniające i barierowe względem światła. Obie melaniny hamowały wzrost Enterococcus faecalis i Pseudomonas aeruginosa.

Wnioski: Nasiona arbuza mogą stanowić obiecujące źródło naturalnej melaniny, która dzięki swoim właściwościom może stanowić uzupełnienie tradycyjnego zastosowania tej rośliny w etnomedycynie.

Słowa kluczowe: melanina, Citrullus lanatus, arbuz, antyoksydanty, substancje antybakteryjne, barierowość względem światła 